\title{
Investigation of anti-Neospora caninum Antibodies in Goats in Mesudiye District of Ordu using ELISA
}

\author{
Deniz ÖZDAMAR ${ }^{1}$, Bilge KARATEPE ${ }^{2 *}$, Alparslan YILDIRIM ${ }^{3}$ \\ ${ }^{1}$ Niğde Ömer Halisdemir University, Graduate School of Natural and Applied Sciences, Biology Department, 51240, Niğde, Turkey \\ ${ }^{2}$ Niğde Ömer Halisdemir University, Bor Vocational School, 51700, Niğde, Turkey \\ ${ }^{3}$ Erciyes University, Faculty of Veterinary Medicine, Department of Parasitology, 38280, Kayseri, Turkey
}

\begin{abstract}
This research was carried out to investigate the seroprevalence of Neospora caninum in goats of Mesudiye district in Ordu province. A total of 184 female goats, which were a year old or more, were randomly selected from five different study sites (Arpaalan, Birebir, Çiftliksarıca, Yeşilçit and Musalı) and the serum samples of the goats were analyzed for anti-N.caninum antibodies by applying ELISA. 16 out of 184 sera (8.69\%) were determined as seropositive for anti-N.caninum antibodies. In terms of age groups, the seropositivity rate was highest in the 2 years old goats $(13.04 \%)$, while no seropositivity was detected in 1-year-old goats. The highest seropositivity rate amongst the study sites was found in Birebir with 36.6\%, whereas none of the goats were seropositive examined in Çiftliksarıca (April) and Yeşilçit. Sixteen (8.98\%) out of 178 non-aborted goats were detected as seropositive, while there was no seropositivity in the 6 goats with abortion history. Neospora caninum seroprevalence was not found to be statistically significant with regards to the age groups of the goats and aborting or non-aborting status $(\mathrm{P}>0.05)$, on the other hand, the results showed statistically significant $(\mathrm{P}<0.001)$ with regards to the research sites. This is the first serological report on N.caninum in goats of Mesudiye district in Ordu province.
\end{abstract} Key Words: Neospora caninum, neosporosis, goat, Ordu-Mesudiye, seroprevalence, ELISA

\author{
$* * *$ \\ Ordu'nun Mesudiye İlçesi Keçilerinde anti- Neospora caninum Antikorlarının ELISA Testi ile \\ Araştırılması
}

ÖZ

$\mathrm{Bu}$ çalışma, Ordu'nun Mesudiye ilçesi keçilerinde Neospora caninum seroprevalansının saptanması amac1 ile yapılmıştır. Araştırmada Mesudiye ilçesindeki 5 farklı çalışma merkezine ait (Arpaalan, Birebir, Çiftliksarıca, Yeşilçit ve Musalı) 1 yaş ve üzerinde rastgele seçilen toplam 184 dişi keçinin kan serumlarında $N$. caninum antikorları ELISA testi ile incelenmiştir. Çalışma ile Ordu'nun Mesudiye ilçesinde incelenen toplam 184 dişi keçinin 16'sı (\%8.69) anti-N. caninum antikorları yönünden seropozitif olarak saptanmışırı. Yaş grupları açısından, en fazla seropozitiflik oranı \%13.04 ile iki yaşındaki keçilerde belirlenmiş, bir yaşındaki keçilerde ise seropozitiflik saptanamamışır. Çalışma merkezleri arasında en yüksek seroprevalans \%36.6 ile Birebir'de belirlenmiş, Çiftliksarıca (Nisan) ve Yeşilçit'de ise seropozitiflik saptanamamıştır. Ayrıca abort görülmeyen 178 keçinin 16's (\%8.98) seropozitif bulunurken, abort geçmişi olan 6 keçinin hiçbirinde seropozitiflik tespit edilememiştir. Neospora caninum seroprevalans oranlanı keçilerin yaş gruplanı ile abort görülen ve görülmeyen keçiler arasında istatistiksel olarak önemsiz bulunmuş ( $\mathrm{P}>0.05)$, çalışma merkezleri açısından ise seropozitifliğin önemli olduğu saptanmıştır $(\mathrm{P}<0.001)$. Ordu'nun Mesudiye ilçesinde keçilerde Neospora caninum ilk defa bu çalı̧ma ile belirlenmiş ve $\% 8.69$ oranında seropozitiflik saptanmıştır.

Anahtar kelimeler: Neospora caninum, neosporosis, keçi, Ordu-Mesudiye, seroprevalans, ELISA

To cite this article: Özdamar D. Karatepe B. Yuldorm A. Investigation of anti-Neospora caninum Antibodies in Goats in Mesudiye District of Ordu using ELISA. Kocatepe Vet J. (2021) 14(1):1-6

Submission: 02.06.2020 Accepted: 04.12.2020 Published Online: 21.12.2020

ORCID ID; DÖ: 0000-0001-9758-3158, BK: 0000-0001-5612-2697, AY: 0000-0001-9868-0363

*Corresponding author e-mail: bkaratepe@ohu.edu.tr 


\section{GİRİş}

Neospora caninum'a ilk defa 1984 yllinda Norveç'te yeni doğan bir köpekte rastlanmış, sinirsel bozukluk ve felç bulguları görülen vakada tespit edilen parazitin morfolojik olarak Toxoplasma gondii'ye benzerlik gösterdiği bildirilmiştir (Dubey ve ark. 1988). Parazitin son konağı köpek olup, ruminantlar, at ve kemirici hayvanlar ara konak görevi görmektedir (McAllister ve ark. 1998).

Neospora caninum'un üç enfeksiyöz dönemi takizoit, bradizoit ve ookistler parazitin naklinde rol oynar. Neosporosiste bulaşma, takizoit veya bradizoit içeren enfekte dokuların yenmesi ve sporlanmış ookistlerin oral alınmas1 sonucu post-natal (horizontal), bunun yanında takizoitlerin gebelik sirasinda enfekte anneden fetüse geçmesi sonucu transplasental olarak (vertikal) gerçekleşebildiği bildirilmiştir (Dubey 2003). Keçilerde semptomlar abort ve ölü doğumlar șeklinde kendini göstermekte ayrıca yeni doğanlarda ensefalit, doğum ağırllğında azalma, meninksler ve omurilikte yang1 görülmektedir. Bunun yanında hastalığın keçi fetüslerinde otoliz ve mumifikasyon, plasentit, diyafram, karaciğer ve akciğerlerde yangiya sebep olduğu bildirilmiştir (Dubey 2003, Bowman 2003).

Keçilerde N. caninum'un prevalansı ülkemizde yapilan çalışmalarla ortaya konulmuş ve farklı prevalans oranlar1 elde edilmiştir (Sevgili ve ark. 2003, Cayvaz ve Karatepe 2011, Utuk ve ark. 2011).

Bu çalışma ile Ordu'nun Mesudiye ilçesi keçilerinde, $N$ caninum'un oluşturduğu neosporosisin seroprevalansının belirlenmesi amaçlanmaktadır.

\section{MATERYAL VE YÖNTEMLER}

\section{Saha Çalışmaları}

Bu araştırma, Şubat-Temmuz 2014 tarihlerinde Ordu ili Mesudiye ilçesinde gerçekleştirilmiştir (Şekil 1). Mesudiye ilçesinin 5 farklı çalışma merkezinde (Arpaalan, Birebir, Çitliksarıca, Musalı, Yeşilçit) halk tarafindan yetiştirilen ve rastgele seçilen 1 yaş ve üzerindeki toplam 184 dişi keçi çalışmanın materyalini oluşturmuştur.

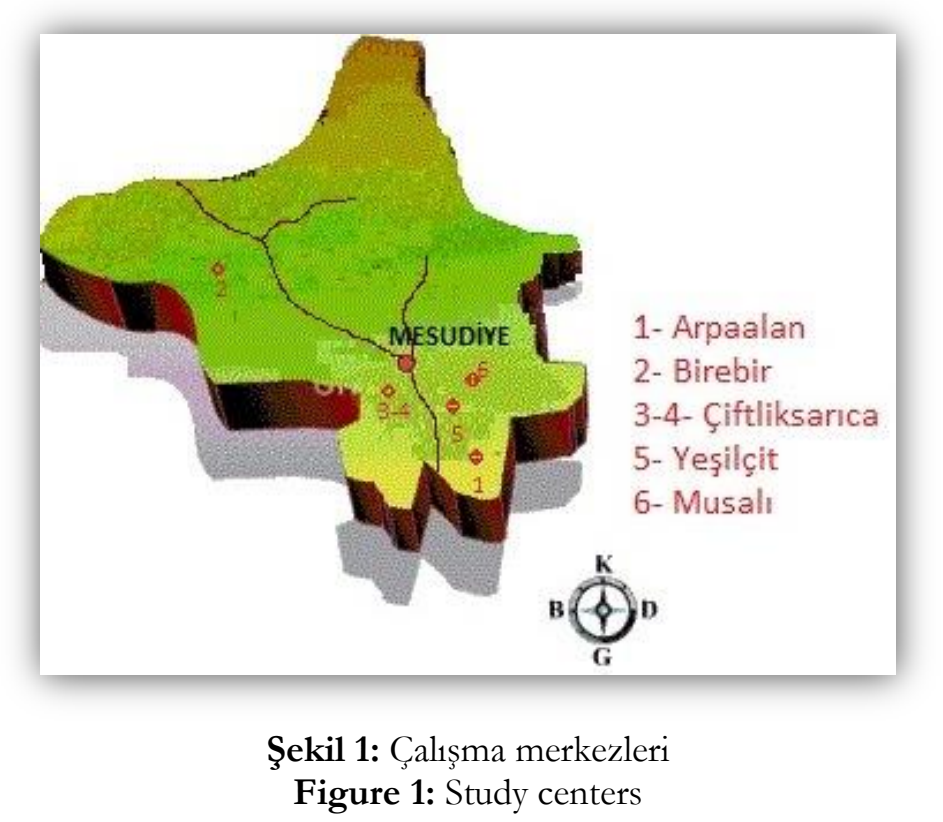

Çalışma merkezlerine çalışma süresince periyodik olarak her ay gidilmiş, Şubat ayında 26 keçi, Mart ayında 30 keçi, Nisan ayında 35 keçi, Mayıs ayında 30 keçi, Haziran ayında 22 keçi ve Temmuz ayında 41 keçi olmak üzere toplam 184 dişi keçinin vena jugularisinden steril vakumlu tüplere tekniğine uygun olarak kan alınmıştır. Keçilerin yaşları ve abort yapmış olma durumları belirlenerek kayıt edilmiştir.

\section{Laboratuvar Çalışmaları}

Keçilerin kan serumları laboratuvarda 3000 rpm'de 10 dakika santrifüj edilerek elde edilmiş ve 1.5 ml'lik eppendorf tüpler içerisinde ELISA ile serolojik muayene yapılıncaya kadar $-20^{\circ} \mathrm{C}$ 'de saklanmıştır.
Neospora caninum antikorlarının belirlenmesi amacı ile ticari kompetatif ELISA (cELISA) kiti (IDEXX, Switzerland AG Stationsstrasse 123097 LiebefeldBern, Switzerland) prosedüründe belirtildiği şekilde kullanılmıştır.

Stop solüsyonu eklendikten hemen sonra, $450 \mathrm{~nm}$ dalga boyunda ELISA cihazında mikrotiter plate okuyucusunda (Mindray MR-96A) saptanan değerler IDEXX kit prosedüründe gösterilen formül ile hesaplanmiştır.

\section{İstatistiksel Değerlendirmeler}

Keçilerde yaş, çalışma bölgeleri ve abort durumu bakımından seropozitiflik oranlarının istatistiksel 
olarak değerlendirilmesinde Ki-kare testi kullanılmıştır.

\section{BULGULAR}

Ordu'nun Mesudiye ilçesine bağlı 5 farklı çalışma merkezinde 1 yaş ve üzerinde toplam 184 dişi keçinin 16'sinda (\%8.69) ELISA testi ile N. caninum seropozitifliği belirlenmiştir.

Tablo 1. Yaş gruplarına göre keçilerde ELISA ile N. caninum seropozitifliği

Table 1. Seropositivity of N. caninum by ELISA in goats according to the age groups

\begin{tabular}{llcc}
\hline Yaş Grupları & \multicolumn{2}{l}{$\begin{array}{l}\text { Muayene Edilen HayvanSeropozitif Hayvan SayısıSeroprevalans (\%) } \\
\text { Sayıs }\end{array}$} \\
\hline 1 yaş & 26 & 0 & 0 \\
2 yaş & 23 & 3 & 13.04 \\
3 yaş & 72 & 6 & 8.3 \\
4 yaş ve üstü & 63 & 7 & 11.11 \\
Toplam & $\mathbf{1 8 4}$ & $\mathbf{1 6}$ & $\mathbf{8 . 6 9}$ \\
\hline (P>0.05) & & &
\end{tabular}

Tablo 1'de belirtildiği gibi yaş grupları açısından; 2 yaşındaki 23 keçinin 3'ünde (\%13.04), 3 yaşındaki 72 keçinin 6'sinda (\%8.33), 4 yaș ve üstü 63 keçinin 7'sinde $\quad(\% 11.11) \quad$ seropozitiflik saptanırken 1 yașındaki keçilerde seropozitiflik belirlenememiștir. Keçilerde yaş bakımından $N$. caninum seropozitifliği istatistiki olarak önemsiz bulunmuştur $(\mathrm{P}>0.05)$.

Tablo 2. Çalışma merkezlerine göre N. caninum'un seropozitifliği

Table 2. Seropositivity of N. caninum according to the study centers

\begin{tabular}{lllll}
\hline Çalışma Merkezi & Aylar & $\begin{array}{l}\text { Muayene } \\
\text { Keçi Sayıs1 }\end{array}$ & $\begin{array}{rlll}\text { EdilenSeropozitif } \\
\text { Sayıs1 }\end{array}$ & KeçiSeroprevalans (\%) \\
\hline Arpaalan & Şubat & 26 & 1 & 3.8 \\
Birebir & Mart & 30 & 11 & 36.6 \\
Cifftliksarıca & Nisan & 35 & 0 & 0 \\
Çiftliksarıca & Mayıs & 30 & 1 & 3.33 \\
Yeşilçit & Haziran & 22 & 0 & 0 \\
Musalı & Temmuz & 41 & 3 & 7.31 \\
TOPLAM & & $\mathbf{1 8 4}$ & $\mathbf{1 6}$ & $\mathbf{8 . 6 9}$ \\
\hline
\end{tabular}

$(\mathrm{P}<0.001)$

Tablo 2'de görüldüğü üzere çalışma bölgeleri açısından N. caninum seropozitifliği; Arpaalan'da 26 keçiden 1'inde (\%3.8), Birebir'de 30 keçiden 11'inde (\%36.6), Çiftliksarıca'da 30 keçiden 1'inde (\%3.33) ve Musalı'da 41 keçiden 3'ünde (\%7.31) saptanmış olup, Nisan ayında Çiftliksarıca'dan alınan 35 keçide ve
Haziran ayında Yeşilçit'ten alınan 22 keçide $N$. caninum antikorları belirlenmemiştir. Çalışma merkezleri açısından Mesudiye yöresinde $N$. caninum varllğg istatistiksel olarak önemli bulunmuştur $(\mathrm{P}<0.001)$.

Tablo 3. Abort yapan ve yapmayan keçilerdeki seropozitiflik

Table 3. Seropositivity in aborted and non-aborted goats

\begin{tabular}{|c|c|c|}
\hline Gruplar & Keçi Sayısı & Seropozitif Keçi Sayı1sı \% \\
\hline Abort Yapan & 6 & 0 \\
\hline Abort Yapmayan & 178 & 8.98 \\
\hline Toplam & 184 & 8.69 \\
\hline
\end{tabular}

$(\mathrm{P}>0.05)$

Tablo 3'de keçilerde abort yapma durumu açısından seropozitiflik durumu verilmiştir. Abort geçmişi olan 6 keçiden hiçbirinde seropozitiflik tespit edilemezken, abort yapmayan 178 keçinin 16'sı (\%8.98) seropozitif belirlenmiştir. Her iki grup arasında seropozitiflik düzeyi karşılaştırıldığında veriler istatistiki olarak önemsiz bulunmuştur $(\mathrm{P}>0.05)$.

TARTIŞMA 
Keçilerde neosporosis, N. caninum tarafindan meydana getirilen abort, ölü doğum ve yeni doğanlarda ensefalitle sonuçlanan önemli bir protozoer enfeksiyondur (Dubey 2003, Dubey ve ark. 2007).

Hastalığın semptomları teşhis açısından yetersiz olduğundan, neosporosisin teşhisinde ELISA, NAT, IFAT ve DAT gibi serolojik analizler ile özellikle moleküler yöntemlerden yararlanılmaktadır. Neosporosisin serolojik teşhisinde özellikle ELISA ve IFAT sıklıkla kullanılan tekniklerdir (Björkman ve Uggla 1999).

Dünyada keçilerde $N$. caninum ile ilgili yapılmış birçok çalışma bulunmaktadır. Bu çalışmalarda; N. caninum Sri Lanka'da 486 keçide ELISA, Western Blot ve IFAT ile \%0.7 (Naguleswaran ve ark. 2004), Brezilya'nın Sao Paulo eyaletinde 394 keçide IFAT ile \%6.4 (Figliuolo ve ark. 2004), Brezilya'nın kuzeydoğu bölgesinde IFAT ile \%3.3 (Faria ve ark. 2007), Brezilya'nın Bahia eyaletinde IFAT ile \%15 (Uzeda ve ark. 2007), Güney Ürdün'de ticari bir enzim immunodeney kiti (Bommeli Diagnostic) ile 300 keçide \%8 (Al-Majali ve ark. 2008), Polonya'da ELISA ve IFAT ile 1060 keçide \%9 (Czopowicz ve ark. 2011), Kuzeydoğu Brezilya'nın Ibimirim eyaletinde IFAT ile 319 keçide \%26.6 (Tembue ve ark. 2011), Romanya'da ELISA ile 512 keçide \%2.3 (Iovu ve ark. 2012), İspanya'da PCR ile 26 keçi fetusunda \%11.5 (Moreno ve ark. 2012), Çek Cumhuriyeti'nde ELISA ile 251 keçide \%6 (Bartova ve Sedlak 2012), Yunanistan'da ELISA ile 375 keçide \%6.9 (Anastasia ve ark. 2013), Doğu Slovakya'da ELISA ile 116 keçide \%15.5 (Cobadiova ve ark. 2013), Romanya'da PCR ile 181 oğlakda \%1.1 (Şuteu ve ark. 2013), Arjantin'de IFAT ile 25 keçide \%8 (Unzaga ve ark. 2014), Brezilya'nın Santa Catarina eyaletinde IFAT ile 654 keçide \%4.58 (Topazio ve ark. 2014) N. caninum seropozitifliği bulunmuştur. Bu çalışmada Mesudiye yöresinde keçilerde saptanan \%8.69'luk prevalans oranının dünyada yapılan bu çalışmalar sonucunda elde edilen prevalans oranlarından farklılık göstermesi, çalışmaların dünyanın değişik coğrafi bölgelerinde yapılmış olmasına, keçilerin yetiştirilme-beslenme şekline ve çalışmalarda kullanılan teşhis yöntemlerine bağlanabilir.

Türkiye'de N. caninum ile ilgili yapılmış birçok çalışma vardır. Bu çalışmalar özellikle sı̆̆ırlar üzerinde gerçekleştirilmiş olup, ayrıca koyun, keçi, at ve köpekler üzerine yapılmış çalışmalar da bulunmaktadır. Türkiye'de keçilerde $N$. caninum ile ilgili yapılmış çalışmalarda ise; Sevgili ve ark. (2003), Şanliurfa'da 85 k1l keçisinin 4'ünde (\%4.7), 95 halep keçisinin 5'inde (\%5.2), Cayvaz ve Karatepe (2011), Niğde yöresinde ELISA testi ile 181 dişi keçinin 47'sinde (\%25.9), Utuk ve ark. (2011), Elazı̆̆, Erzurum ve Kurşehir illerinde ELISA ile 87 Saanen keçisinin 12'sinde (\%13.8) ve 41 Kil keçisinin 1'inde (\%2.4) seropozitiflik bulunmuştur. Yapılan bu çalışmada ise Ordu'nun Mesudiye yöresindeki 184 keçinin 16'sında (\%8.69) N. caninum seropozitifliği saptanmıştır. Bu çalışmada elde edilen seropozitiflik oranının Şanlıurfa yöresinde gerçekleştirilen çalışmada (Sevgili ve ark. 2003) tespit edilen sonuçlardan daha yüksek olduğu, Utuk ve ark. (2011)'nın Elazı̆̆, Erzurum ve Kirşehir yörelerinde elde ettikleri sonuçla (\%13.8) uyumluluk gösterdiği, fakat Cayvaz ve Karatepe (2011)'nin Niğde yöresinde tespit ettikleri sonuçlarla (\%25.9) kıyaslandı̆̆ında ise daha düşük olduğu belirlenmiştir. Bu çalışmalarda elde edilen farklı seroprevalans oranları, araştırmanın yapıldığ1 yöre, keçilerin yetiştirilme şartları, keçi sayısı ve kullanılan serolojik yöntemler gibi faktörlerden kaynaklanabilir.

$\mathrm{Bu}$ araştırmada Ordu'nun Mesudiye yöresindeki 1 yaşındaki keçilerde seropozitiflik oranı belirlenemezken en fazla seropozitiflik oran1 \%13.04 ile 2 yaşındaki keçilerde saptanmıştır. Utuk ve ark. (2011) Elazı̆̆, Erzurum ve Kırşehir yörelerinde N. caninum seropozitifliğini 2-4 yaş arası keçilerde saptadıklarını bildirmişlerdir. Sevgili ve ark. (2003) Şanlıurfa yöresi keçilerinde yaş grupları açısından seropozitiflik oranı arasında istatistiksel fark bulamadığını belirtmiştir. Cayvaz ve Karatepe (2011) Niğde yöresinde keçilerde yaş bakımından N. caninum seropozitifliğini önemli olarak bildirmişlerdir. Yapılan bu çalışmada ise keçilerde yaş bakımından $N$. caninum'un seropozitifliği istatistiksel açıdan önemsiz olarak tespit edilmiştir $(\mathrm{P}>0.05)$. Bu farklllıkların nedeni çalışmaların farklı bölgelerde yapılmış olmasına ve çalışmada kullanılan keçilerin sayısı ve 1rkına bağlanabilir.

Bu araştırmada Ordu'nun Mesudiye yöresindeki keçilerde çalışma bölgeleri bakımından $N$. caninum seropozitifliği istatistiki açıdan anlamlı belirlenmiş $(\mathrm{P}<0.001)$ en yüksek oran \%36.6 ile Birebir köyünde saptanırken Çiftliksarıca (Nisan ay1) ve Yeşilçit köyündeki keçilerde ise $N$. caninum seropozitifliği belirlenememiştir. $\mathrm{Bu}$ sonuç araştırmaların gerçekleştirildiği çalışma merkezlerinde uygulanan farklı yetiştirme koşullarına ve son konak köpeklerin sayısı ile bunların keçilerin ağıl, yem ve suları ile temasındaki farklılıklarla ilişkili olabilir.

Bunun yanında bu çalışmada abort yapan ve yapmayan keçilerde $N$. caninum seropozitifliğinin varlığı karşılaştırıldığında elde edilen veriler istatistiki açıdan önemsiz olarak tespit edilmiştir $(\mathrm{P}>0.05)$. Bu sonuç Niğde yöresinde Cayvaz ve Karatepe (2011)'nin keçilerin abort yapma oranlarında buldukları istatistiksel sonuçla uyum göstermektedir.

Küçükbaş hayvan yetiştiriciliğinde önemli ekonomik kayiplara sebep olan neosporosisin biyolojisinde son konak köpekler önemli rol oynamaktadır. Bu sebeple enfeksiyondan korunma ve kontrolde, sokak köpeklerinin sayısı sınırlandırılmalı, köpek dışkıları keçilerin çevresinden arındırılarak keçilerin otladığ1 mera alanlarına ve ağıllara, yem ve su kaynaklarına teması engellenmelidir. Plasental membranlar ve atık fetus kalıntıları ve çiğ etlerin köpekler tarafından yenilmesine engel olunmalı ve son konak köpeklerin 
keçilerin yem ve suları ile kontaminasyonu önlenmelidir.

Sonuç olarak, bu çalışma ile Mesudiye yöresindeki keçilerde $N$. caninum'un varlığ1 ve yaygınlı̆̆1 saptanmıştır. Enfeksiyonun keçilerde abortlara ve ölü doğumlara neden olabileceği dikkate alındığında özellikle küçükbaş hayvanlarda abortların sebeplerinin araştırıldığ1 çalışmalarda neosporosis'in de göz önünde tutulmasının faydalı olacağı düşünülmektedir.

Proje Destek Bilgileri : Niğde Ömer Halisdemir Üniversitesi Bilimsel Araştırma Projeleri Birimi tarafindan FEB 2013/32-YÜLTEP kodu ile desteklenmiştir.

Tez Bilgileri : İlk isim yazarın Yüksek Lisans Tezi'nden özetlenmiștir.

Etik Kurul Bilgileri : Erciyes Üniversitesi Hayvan Deneyleri Etik Kurulu, 09.10.2013 tarih ve 13/121 Nolu Karar

\section{KAYNAKLAR}

Al-Majali AM, Jawasreh KI, Talafha HA, Talafha AQ. Neosporosis in Sheep and Different Breeds of Goats from Southern Jordan: Prevalence and Risk Factors Analysis. Am J Anim Vet Sci. 2008; 3: 47-52.

Anastasia D, Elias P, Nikolaos P, Charilaos K, Nektarios G. Toxoplasma gondii and Neospora caninum seroprevalence in dairy sheep and goats mixed stock farming. Vet Parasitol. 2013; 198: 387-390.

Bartova E, Sedlak K. Toxoplasma gondii and Neospora caninum antibodies in goats in the Czech Republic. Vet MedCzech. 2012; 57: 111-114.

Björkman C, Uggla A. Serological diagnosis of Neospora caninum infection. Int J Parasitol. 1999; 29: 1497-1507.

Bowman DD, Lynn RC, Eberhard ML. Georgis Parasitology for Veterinarians. Elsevier Science, USA, 2003.

Cayvaz M, Karatepe M. Niğde Yöresi Keçilerinde Neospora caninum'un Seroprevalansı. Kafkas Univ Vet Fak Derg. 2011; 17: 935-939.

Cobadiova, A., Reiterova, K., Derdakova, M., Spilovska, S., Turcekova, L., Hviscova, I. Hisira, V. Toxoplasma gondii, Neospora caninum and tick-transmitted bacterium Anaplasma phagocytophilum infections in one selected goat farm in Slovakia. Acta Parasitol 2013; 58: 541-546.

Czopowicz M, Kaba J, Szalu's-Jordanow O, Nowicki M, Witkowski L, Frymus T. Seroprevalence of Toxoplasma gondii and Neospora caninum infections in goats in Poland. Vet Parasitol. 2011; 178: 339-341.

Dubey JP. Review of Neospora caninum and neosporosis in animals. Korean J Parasitol. 2003; 41: 1-16.

Dubey JP, Carpenter JL, Speer CA, Topper MJ, Uggla A. Newly recognized fatal protozoon disease of dogs. J Am Vet Med Assoc. 1988; 192: 1269-1285.
Dubey JP, Schares G, Ortega-Mora LM. Epidemiology and Control of Neosporosis and Neospora caninum. Clin Microbiol Rev. 2007; 20: 323-367.

Faria EB, Gennari SM, Pena HFJ, Athayde ACR, Silva MLCR, Azevedo SS. Prevalence of anti- Toxoplasma gondii and anti-Neospora caninum antibodies in goats slaughtered in the public slaughterhouse of Patos city, Parar'ba State, Northeast region of Brazil. Vet Parasitol. 2007; 149:126-129.

Figliuolo LPC, Rodrigues AAR, Viana RB, Aguiar DM, Kasai N, Gennari SM. Prevalence of anti-Toxoplasma gondii and anti-Neospora caninum antibodies in goat from São Paulo State, Brazil. Small Ruminant Res. 2004; 55: 29-32.

Iovu A, Györke A, Mircean V, Gavrea R, Cozma V. Seroprevalence of Toxoplasma gondii and Neospora caninum in dairy goats from Romania. Vet Parasitol 2012; 186: $470-474$.

McAllister MM, Dubey JP, Lindsay DS, Jolley WR, Wills RA, McGuire AM. Dogs are definitive hosts of Neospora caninum. Int J Parasitol. 1998; 28: 1473-1478.

Moreno B, Collantes-Fernandez E, Villa A, Navarro A, Regidor-Cerrillo J, Ortega-Mora LM. Occurrence of Neospora caninum and Toxoplasma gondii infections in ovine and caprine abortions. Vet Parasitol. 2012; 187: 312-318.

Naguleswaran A, Hemphill A, Rajapakse RPVJ. Sager H. Elaboration of a crude antigen ELISA for serodiagnosis of caprine neosporosis: validation of the test by detection of Neospora caninum-specific antibodies in goats from Sri Lanka. Vet Parasitol. 2004; 126: 257-262.

Sevgili M, Çimtay İ, Keskin O. Şanlıurfa Yöresindeki Keçilerde Neospora caninum Enfeksiyonunun Seroprevalansı. Türkiye Parazitol Derg. 2003; 27: 249-251.

Şuteu O, Paştiu A, Györke A, Avram E, Cozma V. Molecular detection of Neospora caninum in slaughtered goat kids from Romania. Sci Parasitol. 2013; 14: 43-46.

Tembue AASM, Ramos RAN, Sousa TR, Albuquerque AR, Costa AJ, Meunier IMJ, Faustino MAG, Alves LC. Serological survey of Neospora caninum in small ruminants from Pernambuco State, Brazil. Rev Bras Parasitol Vet. 2011; 20: 246-248

Topazio JP, Weber A, Camillo G, Vogel FF, Machado G, Ribeiro A, Moura AB, Lopes LS, Tonin AA, Solda NM, Braunig P, Silva AS. Seroprevalence and risk factors for Neospora caninum in goats in Santa Catarina state, Brazil. Rev Bras Parasitol Vet. 2014; 23: 360-366.

Unzaga JM, More G, Bacigalupe D, Rambeaud M, Pardini L, Dellarupe A, Felice LD, Gos ML, Venturini MC. Toxoplasma gondii and Neospora caninum infections in goat abortions from Argentina. Parasitol Int. 2014; 63: 865867.

Utuk AE, Simsek S, Piskin FC, Balkaya I. Detection of Neospora caninum $\operatorname{IgG}$ Antibodies in Goats in Elazig, Erzurum and Kirsehir Provinces of Turkey. Isr J Vet Med. 2011; 66: 157-160.

Uzeda RS, Pinheiro AM, Fernandez SY, Ayres MCC, Gondim LFP, Almeida MAO. Seroprevalence of 
Neospora caninum in dairy goats from Bahia, Brazil. Small Ruminant Res. 2007; 70: 257-259. 